Perinatology pISSN 2508-4887 • elSSN 2508-4895
Case report

Perinatology Vol. 31, No. 2, June, 2020 https://doi.org/10.14734/PN.2020.31.2.103

\title{
Preterm Delivery due to Listeriosis in Third Trimester Pregnancy
}

\author{
Gun Gu Kang, MD, \\ Ji Yeon Choi, MD, \\ Seung Woo Yang, MD, PhD, \\ Han Sung Kwon, MD, PhD, \\ In Sook Sohn, MD, PhD, \\ Han Sung Hwang, MD, PhD
}

Division of Maternal and Fetal Medicine, Department of Obstetrics and Gynecology, Research Institute of Medical Science, Konkuk University School of Medicine, Seoul, Korea

Received: 24 February 2020

Revised: 3 April 2020

Accepted: 6 April 2020

Correspondence to Han Sung Hwang, MD, PhD Department of Obstetrics and Gynecology, Konkuk University School of Medicine, 120-1 Neungdong-ro, Gwangjin-gu, Seoul 05030, Korea

Tel: +82-2-2030-7747

Fax: +82-2-2030-7748

E-mail: hwanghs@kuh.ac.kr

Copyright@ 2020 by The Korean Society of Perinatology

This is an Open Access article distributed under the terms of the Creative Commons Attribution Non-Commercial License (http://creativecommons.org/ license/by-nc/4.0/), which permits unrestricted non-commercial use, distribution, and reproduction in any medium, provided that the original work is properly cited.
Listeria monocytogenes is a ubiquitous pathogen in the environment, capable of causing human and animal infection. Listeriosis is predominantly a foodborne illness caused by consumption of food contaminated with listeria. Listeriosis in pregnancy can cause miscarriage, stillbirth and preterm labor. Listeria monocytogenes is the causative agent of serious infection such as meningoencephalitis and septicemia with about $25 \%$ mortality rate. The frequency is as high as $50 \%$ in neonates. We experienced a case of listeriosis in a singleton pregnancy at 28rd week of gestation that presented with fever, chill, lower abdominal pain, and eventually resulted in fetal distress and we finally performed emergency cesarean section. Pathologic results of the placenta, as well as blood and amniotic fluid culture of the mother confirmed Listeria monocytogenes infection. Neonatal blood culture also confirmed Listeria monocytogenes infection and neonate presents septicaemia, respiratory distress and granulomatosis infantisepticum. High-dose ampicillin, imipenem, cilastatin was used to Neonate and improved neonatal outcome and discharged.

Key Words: Listeria monocytogenes, Fetal distress, Cesarean section

서론

Listeria monocytogenes는 그람양성 단구 형태의 세균으로 리스테리아 속(genus) 중 유 일한 인간 감염을 일으킨다. ${ }^{1-3}$ Listeria monocytogenes는 음식으로부터 전파되는 병원체로 30 도에서 37 도 사이에서 가장 잘 자라며 살균되지 않은 우유, 치즈, 덜 익은 고기, 채소 같은 감염된 음식으로 인하여 감염된다. ${ }^{4,5}$ 냉장보관의 발달로 최근 리스테리아증 감염 사례가 증 가하고 있다. ${ }^{2,6}$ 리스테리아는 면역 저하 환자, 신생아 또는 노인에서는 뇌수막염이나 패혈증 을 일으키며, 산모에서는 조산, 유산, 사산, 신생아 패혈증 등을 일으킨다. ${ }^{7.8}$ 또한, 리스테리아 균은 장 점막, 태반을 통과하며 태아에게 수직 감염을 일으킨다. ${ }^{6}$

임산부는 세포 매개 면역성이 일반 인구보다 떨어져 있기 때문에 리스테리아에 감염되기 쉽다. ${ }^{3,6}$ 늦은 임신 주수에 감염될수록 예후가 좋지 않으며 융모양막염을 동반하고 신생아에 서 사망, 패혈증, 급성 호흡곤란, 괴사성 육아종증, 분만 후 신경학적 문제들도 발생 가능하 다. ${ }^{1,2,6}$ 임산부 리스테리아증은 무증상이거나 발열, 오한 등의 독감 증상, 비특이적인 장염 증 상 등 경미한 증상을 보이기 때문에 놓치기 쉽다.,3,5 이에 저자들은 특이 과거력이 없고 산전 진찰에서 특별한 이상 징후가 없었던 산모의 조산, 출산 후 신생아 패혈증, 신생아 피부의 육 아종증 소견과 더불어 신생아의 혈액, 산모의 양수, 혈 액배양검사를 통하여 리스테리아에 합 당한 소견을 확인하였기에 문헌고찰과 함께 보고하는 바이다.

\section{증례}

환자: 김OO (24세)

주소 및 현병력: 상기 24세 초산모는 임신 28주 3일에 고열, 오한, 설사, 태동 감소 증상으 로 내원하였다. 입원 전일부터 고열, 태동 감소 증상이 지속되어 개인병원을 방문하였고 해 
열제 투여 후에도 지속적인 태아 심박수 증가 소견을 보여 본원 으로 전원되어 입원하였다. 환자의 의식은 명료하였으며 전신 상태는 양호하였다. 산모는 평소 음식점에서 식사를 하지 않았 으며 설사, 발열을 유발할 수 있는 상한 음식을 먹지 않았다고 하 였고 주로 집에 있는 냉동식품 등으로 조리하여 식사를 하였다 고 하였다.

산과력: 0-0-0-0으로 이전 산과력이 없는 초산모였다.

과거력: 산모는 고혈압, 당뇨, 결핵, 임신중독증 등의 과거력 은 없었다. 개인병원에서 시행한 산전검사상 특이 소견은 없었 으며 초음파검사상 태아는 주수에 맞게 크고 있었고 genetic screening에서 특이 소견은 발견되지 않았다.

가족력 및 기왕력: 가족 중 고혈압, 당뇨, 결핵, 그 외에 자가면 역 질환이나 유전성 질환 등의 특이 소견은 없었다.

신체검사 소견: 입원 당시 혈압은 $124 / 71 \mathrm{mmHg}$, 맥박 138회/ 분, 호흡 24 회/분이었고 체온은 $38.4^{\circ} \mathrm{C}$ 로 상승된 소견이었다. 환 자의 호흡음은 정상이었고 코막힘 증상은 있었으나 상기도 시진 상 인두 발적이나 편도 비대는 보이지 않았다. 복부 진찰에서 복 부 팽만은 관찰되지 않았고 복부 압통, 반발통도 없었다. 질경검 사에서 자궁경부는 닫혀 있었으며 양막파수 소견 및 질 분비물 은 관찰되지 않았다. 비수축검사상 태아 심박수는 190회/분이 었고 자궁 수축은 1-3분 간격으로 15-30 mmHg의 강도를 보였 으며 간헐적인 가변성 감퇴 소견을 보였다.

검사실 검사 소견: 말초혈액검사에서 백혈구 $15,940 / \mathrm{mm}^{3}$, 혈색소 $10.4 \mathrm{~g} / \mathrm{dL}$, 혈소판 수치는 정상이었다. 혈액응고검사, 간기능검사, 신기능검사, 요검사에서 특이 소견은 없었다. 화 학검사상 C-reactive protein (CRP) $3.74 \mathrm{mg} / \mathrm{dL}$, 혈청검사에 서는 Toxoplasma immunoglobulin M (IgM) Ab (-), Cytomegalovirus IgM Ab (-), rubella IgM Ab (-), Herpes simplex virus $\operatorname{IgM~Ab}(-)$ 결과를 보였다. 특수 미생물검사에서 influenza $\mathrm{Ag}(-)$ 결과를 보였으며, 질 분비물 검사에서는 Ureaplasma parvum 2+ 소견을 보였다.
초음파 소견: 태아 선진부는 두정위였고 태아의 양두정골 직 경은 $68.6 \mathrm{~mm}$ (27주), 장골 길이는 $52.8 \mathrm{~mm}$ (28주), 복부 둘레 는 $252 \mathrm{~mm}$ (29주)로 태아 추정 몸무게는 $602 \mathrm{~g}$ 이었다. 태반은 자궁 전벽에 위치하였으며 양수량은 풍부하였다. 자궁경부의 길 이는 $38.5 \mathrm{~mm}$ 였고 자궁경부 개대 소견은 관찰되지 않았다.

입원 경과: 입원 당일 융모양막염 의심하에 혈액, 양수, 소변, 질 분비물을 채취하여 배양검사를 시행하였다. 혈액검사 결과 가 나오기 전 경험적 항생제로 ampicillin $1 \mathrm{~g}$, sulbactam $0.5 \mathrm{~g}$ 을 하루에 네 차례 정주하고 수액 요법과 acetaminophen을 정맥으 로 투여하였다. 해열제 투여 후 1 시간 30 분 뒤 체온은 $36.5^{\circ} \mathrm{C}$ 로 내려갔다. 이후 2 시간 뒤 체온은 $37.6^{\circ} \mathrm{C}$ 로 다시 올라갔으며 비 수축검사상 지속적인 태아 심박수 감소로 태아가사 소견을 보 여(Fig. 1), 임신 28주 4일에 응급 제왕절개 분만술을 시행하였 고, 2019년 3월 5일 오후 11시 28분 1,200 g의 여아를 출산하였 다. 태변 착색 양수 소견은 관찰되지 않았으며 태반은 $468 \mathrm{~g}$ 이었 고, 외관상 특이 소견은 없어 태반 조직 병리검사 결과 융모양막 염으로 진단되었다(Fig. 2). 제 대혈관은 동맥 2개, 정맥 1개로 정 상이었다.

양수 세균배양검사에서 단구성 리스테리아 외에 다른 균은 동 정되지 않았다. 산모의 혈액배양검사에서 양수에서와 같이 단구 성 리스테리아로 외에 다른 균은 동정되지 않았다. 수술 후 1 일 째 시행한 혈액검사상 백혈구 $18,060 / \mathrm{mm}^{3}$, 혈색소 $9.4 \mathrm{~g} / \mathrm{dL}$ 였 다. 기존 항생제 중단 후 ampicillin $2 \mathrm{~g}$ 을 매 4시간마다 투여하였 고, 수술 후 4 일째 산모는 특이 증상이나 후유증 없이 활력 징후 가 안정적이어서 2019년 3월 10일 amoxicillin $1 \mathrm{~g}$, 하루 3회의 경구용 항균제를 지참하여 퇴원하였다.

신생아 검사 소견: 태어난 여아의 혈압은 $52 / 22 \mathrm{mmHg}$, 맥 박 154회/분, 호흡 40회/분이었다. 출생 시 시행한 혈액검사에 서 혈색소 $10.4 \mathrm{~g} / \mathrm{dL}$, 적혈구 용적은 $37.5 \%$ 였으며 화학검사상 $\mathrm{CRP}$ 가 $4.15 \mathrm{mg} / \mathrm{dL}$ 로 증가한 상태였다. 여아는 호흡곤란이 있 으면서 전신이 창백하며 힘없이 처져있는 모습을 보였다. 출생

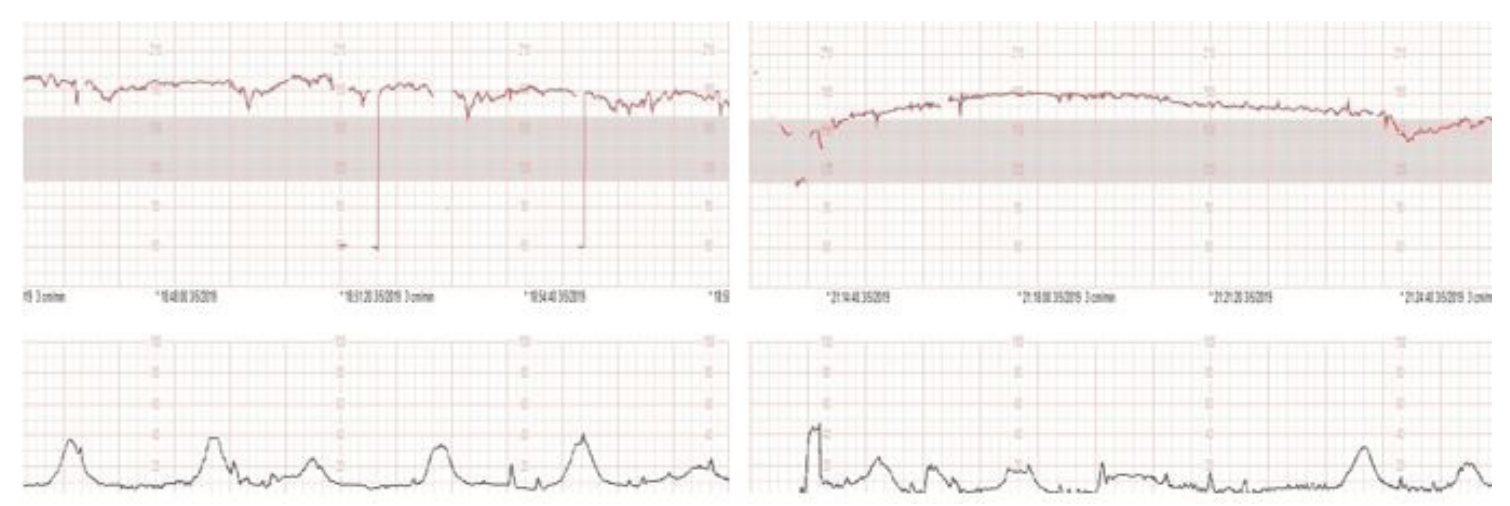

Fig. 1. Non-stress test show fetal tachycardia and fetal distress. 


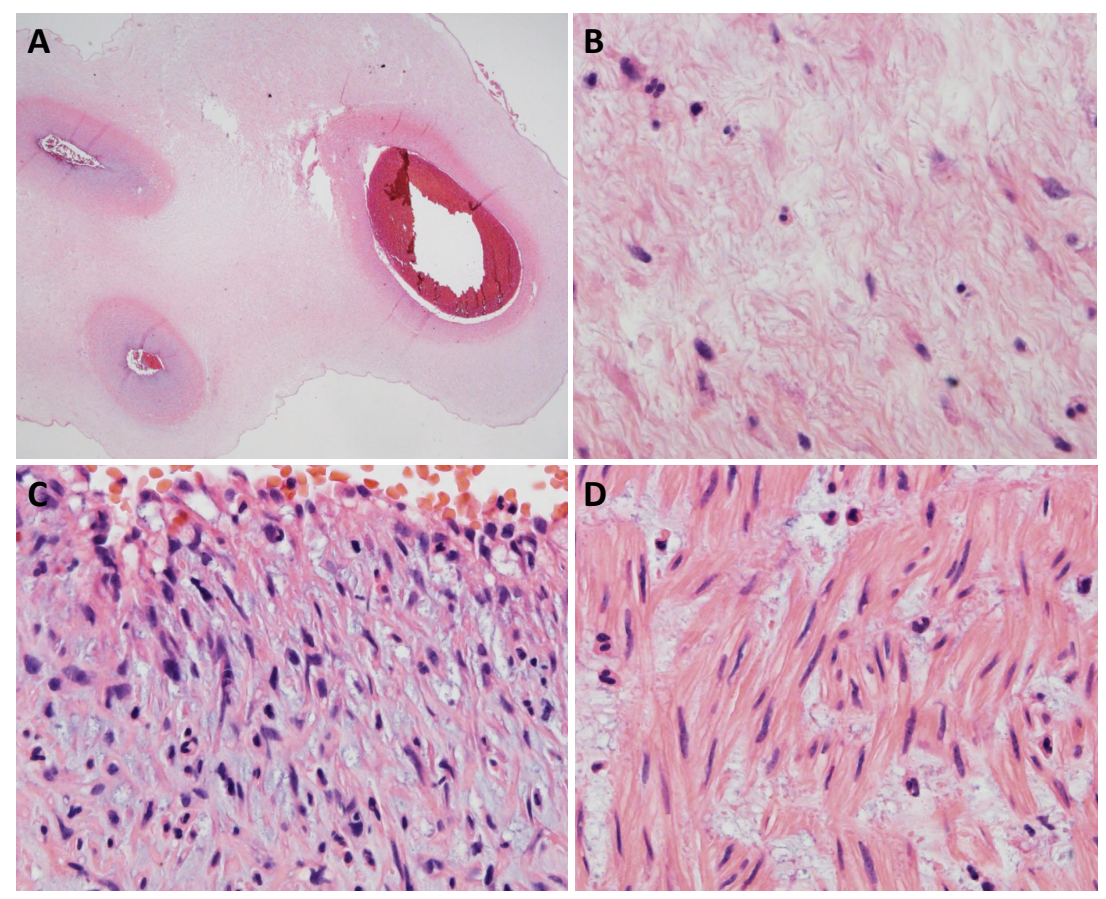

Fig. 2. Pathology of acute chorioamnionitis and funisitis of placenta $(A: H \& E, \times 200 ; B-D$ : $\mathrm{H} \& \mathrm{E}, \times 400)$. H\&E, hematoxylin and eosin.

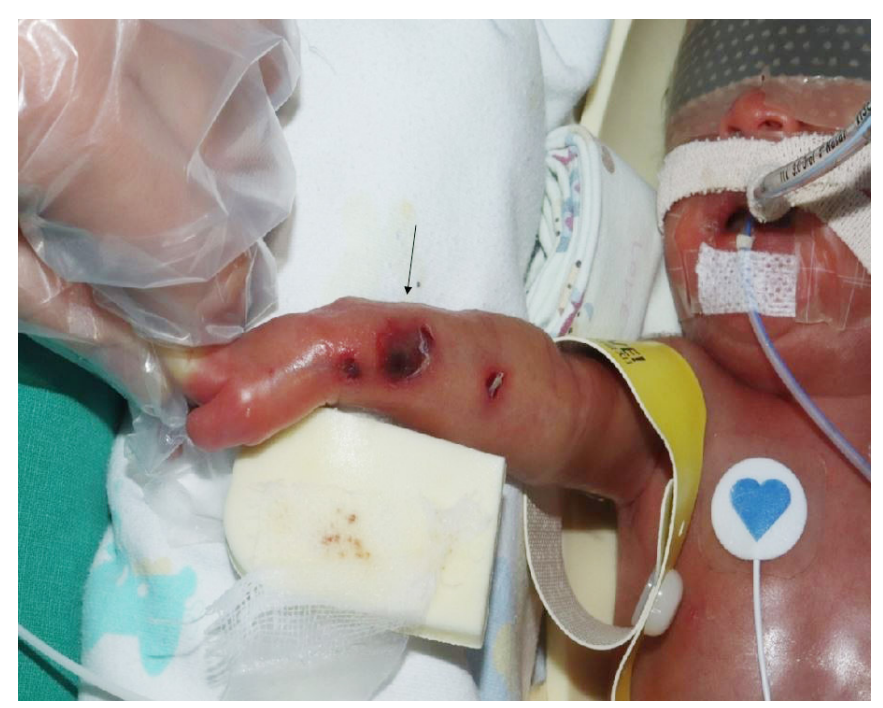

Fig. 3. Granulomatosis infantisepticum in neonate.

시 아프가(Apgar) 점수는 1 분에 2점, 5 분에 2점으로 신생아 중 환자실로 입원하여 기도 내 삽관을 시행하였다. 여아의 혈액배 양검사에서도 단구성 리스테리아로 동정되었다. 여아의 오른 쪽 팔과 다리에 육아종 소견이 관찰되었고(Fig. 3), 흉부 엑스 레이 검사에서 급성 호흡곤란 증후군에 합당한 소견을 보였으 며(Fig. 4A), 여아는 패혈증으로 진단되어 2일간 vancomycin, imipenem 정맥 투여와 기계환기 치료를 하였다. 2 일 뒤 여아의 혈액검사에서 단구성 리스테리아가 동정되어 vancomycin에서 ampicillin 정맥 투여로 항생제를 변경하였다. 신생아 뇌수막염 방지를 위하여 항생제는 3 주간 유지하였고, 입원 17 일째 발관하 였으며, 입원 65일째 경과 호전되어 퇴원하였다(Fig. 4B). 퇴원 당시 여아는 심장 초음파상 심방중격결손 소견을 보였고, 뇌 자 기공명영상 촬영에서 두개내 출혈, 뇌실내 출혈, 지주막하출혈 소견을 보여 6 개월 뒤 추적관찰 예정이다.

\section{고찰}

Listeria monocytogenes는 10개의 리스테리아 속 중에서 유 일하게 인간 감염을 일으키는 그람양성 통성 혐기성 간균으로, 장의 점막 장벽을 통과하여 혈액 속으로 침투한다. ${ }^{6}$ 리스테리아 는 어떤 장기에도 퍼질 수 있지만 주로 태반이나 중추신경계를 잘 침범한다. ${ }^{2,6}$ 리스테리아는 건강한 사람에서는 감염을 잘 일 으키지 않으며 감염된 경우에도 감기, 발열, 설사 같은 경미한 증 상만 보인다. ${ }^{9}$ 스테로이드를 사용하는 환자, 만성 신부전 환자, 간경화증 환자, 비장절제 환자, Human immunodeficiency virus 감염 환자, 당뇨 환자, 신생아, 임산부, 노인 등과 같이 세포 매개 면역이 저하된 환자 등은 리스테리아증의 고위험군이다. ${ }^{8,9}$ 임산 부는 세포 매개 면역성이 일반 인구보다 떨어져 있기 때문에 리 스테리아에 감염되기 쉅다. ${ }^{3,6}$ 일반 인구에서 리스테리아 감염은 10 만 명당 0.7 명으로 보고되고 임산부에서는 10 만 명당 12 명 


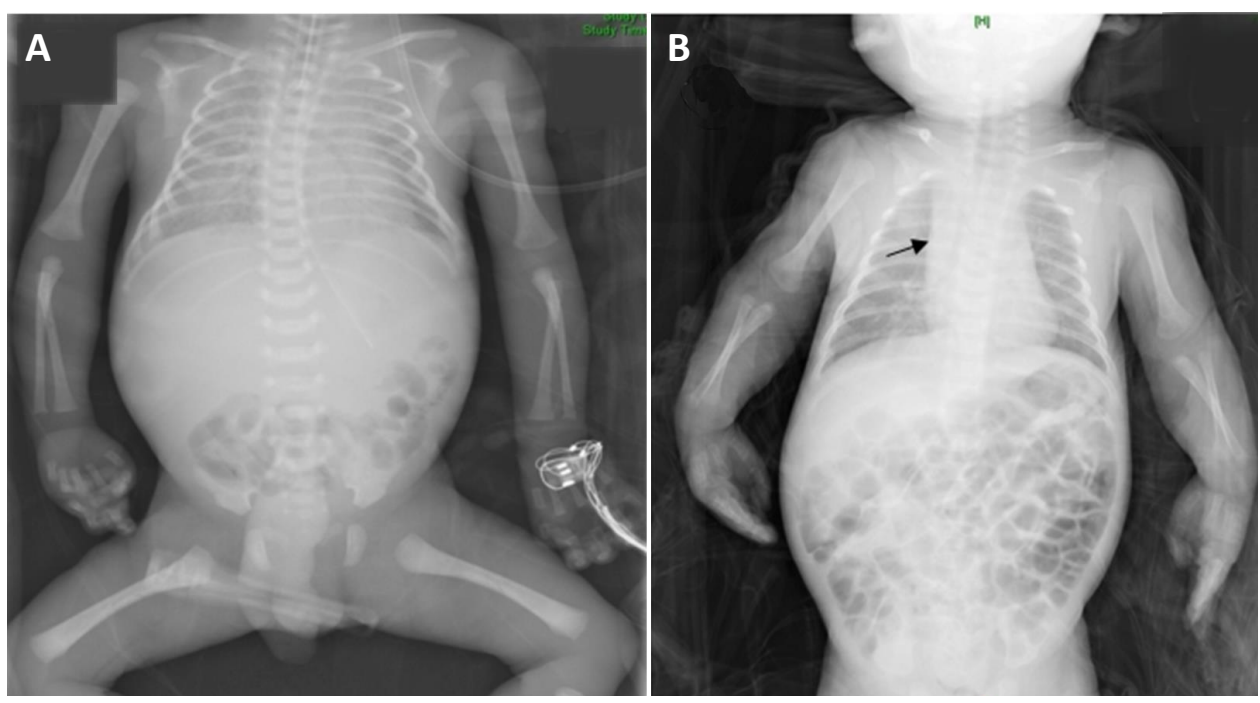

Fig. 4. (A) The infantogram shows acute respiratory distress syndrome (ARDS). (B) Improved ARDS since first study and rule out linear atelectasis (arrow) at in right low lung field.

으로 일반 인구에서 비하여 17 배나 더 흔한 것으로 나타났다. ${ }^{10}$

리스테리아증은 음식 매개 감염증으로 리스테리아균은 토양, 대변에서 자라고 동물에게 섭취되어 인간에게 감염된다. ${ }^{6}$ 인간 의 몸으로 흡수된 리스테리아균은 위장관을 따라 증식하며 막을 파괴하지 않아 항체, 중성구, 항생제에 노출되지 않는다. ${ }^{6}$ 리스 테리아균은 장이나 태반 장벽을 통과할 수 있고 그로 인하여 태 아에게 수직 감염을 일으킨다. ${ }^{6}$

리스테리아증 감염 경로는 주로 상한 채소, 핫도그, 멸균되지 않은 유제품, 훈제 연어, 육류, 덜 익힌 생선이다. ${ }^{4,6,11}$ MacDonald 등 $^{11}$ 이 보고한 케이스를 보면 멕시코에서 멸균되지 않은 우유로 만든 치즈를 섭취한 임산부에서 리스테리아 감염이 발견된 사례 가 있다. ${ }^{11}$ 리스테리아는 냉장 온도에서 증식을 하며 냉장고의 발달로 인하여 음식의 보관이 길어지면서 리스테리아증의 유병 률도 증가하고 있다. ${ }^{2,6}$

임산부 리스테리아증은 무증상이거나 발열, 몸살 등의 독감 증상, 비특이적인 장염 증상 같은 경미한 증상을 보이지만 태아 와 신생아에게는 치명적인 증상을 유발한다. ${ }^{12,13}$ 임산부 리스테 리아증은 산모의 조기 진통과 동반된 태아가사, 조기 양막파수, 유산 및 사산을 유발한다..$^{5,6,12,13}$ Sapuan 등 ${ }^{5}$ 이 보고한 내용을 보 면 임산부 리스테리아증의 19\%는 유산과 사산을 유발하고 35\% 는 신생아 사망을 유발한다. ${ }^{5}$ 감염된 신생아는 주로 폐렴으로 진 단되며 패혈증/균혈증, 뇌수막염, 괴사성 육아종증 같은 특징적 인 피부 소견 등이 보고되었다. ${ }^{5,6,9}$ 본 증례에서 여아는 급성 호 흡곤란증을 유발하는 폐렴, 패혈증/균혈증, 팔과 다리에 괴사성 육아종증 소견이 관찰되었다.

임산부 리스테리아증은 경미하고 비특이적인 증상을 보이기
때문에 초기 검사를 하지 않아 놓치기 쉅다. ${ }^{14}$ 임산부 중 발열, 조 기 진통과 동반된 태아곤란, 조기 양막파수 증상이 보인다면 일 반적인 감염균과 함께 리스테리아 역시 의심해야 하며 검사와 함께 진단이 확정되기 전에 항생제 치료를 시작해야 한다. ${ }^{2,3,5}$ 검 사는 주로 산모와 신생아의 혈액배양검사를 하며 증상이 있는 산모에서 양수천자를 시도해볼 수 있다. ${ }^{6-8}$ 대변배양검사는 민 감성이 낮기 때문에 시행하지 않는다. ${ }^{14}$ Park 등 ${ }^{14}$ 이 보고한 케이 스를 보면 태반 조직검사에서 융모양막염 소견을 보였으며 국소 적 괴사를 동반한 다수의 미세 농양과 출혈이 발견되었고 본 증 례에서도 태반 조직검사에서 융모양막염 소견을 보였다. ${ }^{6}$

임산부 리스테리아증이 의심되거나 진단되면 penicillin 혹은 ampicillin을 하루 $6 \mathrm{~g}$ 이상 정맥주사로 7-14일간 투여하여야 한 다. ${ }^{6,12}$ American College of Obstetricians and Gynecologists 가이드라인에 따르면 임산부 리스테리아증의 치료로 ampicillin 이 가장 효과적이며 하루 $6 \mathrm{~g}$ 이상, $2 \mathrm{~g}$ 씩 8시간마다 7-14일간 투여할 것을 권고한다. 어떤 전문가들은 발열 증상이 동반되면 하루 $12 \mathrm{~g}$ 의 ampicillin과 하루 $3 \mathrm{~g}$ 의 amoxicillin을 정맥주사로 투여하는 것을 권한다. ${ }^{6}$ 또한 gentamycin도 ampicillin의 효과를 돕기 위하여 같이 사용해볼 수 있다. 발열 증상이 없으나 리스테 리아균에 오염된 음식에 노출된 경우 $1 \mathrm{~g}$ 의 amoxicillin을 하루 3번 총 14 일간 정맥주사로 투여한다. ${ }^{6}$ 산모가 penicillin에 알레 르기가 있으면 두 번째 선택으로 erythromycin을 하루 $4 \mathrm{~g}$ 정맥 주사로 7-14일간 투여할 수 있다. ${ }^{6,12}$ 저자들은 태어난 아기의 패 혈증 진단과 선천성 리스테리아증에서 볼 수 있는 피부의 육아 종 소견을 경험하였고 고열, 오한, 설사 증상을 동반한 독감 및 장염 증상을 보인 임신 28 주 산모와 아기의 혈액 및 양수배양검 
사에서 단구성 리스테리아가 동정되었으며, 태아곤란 증상을 보 여 산모의 조기 진통, 조기 분만의 증례를 경험하였기에 간단한 문헌고찰과 함께 보고하는 바이다.

\section{References}

1) Awofisayo A, Amar C, Ruggles R, Elson R, Adak GK, Mook P, et al. Pregnancy-associated listeriosis in england and wales. Epidemiol Infect 2015;143:249-56.

2) Barikbin $P$, Sallmon $H$, Hüseman $D$, Sarioglu $N$, Weichert $A$, von Weizsäcker K, et al. Clinical, laboratory, and placental findings in perinatal listeriosis. Fetal Pediatr Pathol 2016;35:307-14.

3) Bubonja-Sonje M, Mustac E, Brunn A, Deckert M, Abram M. Listeriosis in pregnancy: case report and retrospective study. J Matern Fetal Neonatal Med 2013;26:321-3.

4) Girard D, Leclercq A, Laurent E, Lecuit M, de Valk H, Goulet V. Pregnancyrelated listeriosis in France, 1984 to 2011, with a focus on 606 cases from 1999 to 2011. Euro Surveill 2014;19:20909.

5) Sapuan S, Kortsalioudaki C, Anthony M, Chang J, Embleton ND, Geethanath RM, et al. Neonatal listeriosis in the UK 2004-2014. J Infect 2017;74:236-42.

6) Craig AM, Dotters-Katz S, Kuller JA, Thompson JL. Listeriosis in pregnancy: a review. Obstet Gynecol Surv 2019;74:362-8.

7) Elinav $H$, Hershko-Klement A, Valinsky L, Jaffe J, Wiseman A, Shimon $H$, et al. Pregnancy-associated listeriosis: clinical characteristics and geospatial analysis of a 10-year period in Israel. Clin Infect Dis 2014;59:95361

8) Fouks Y, Amit S, Many A, Haham A, Mandel D, Shinar S. Listeriosis in pregnancy: under-diagnosis despite over-treatment. J Perinatol 2018; 38:26-30

9) Elinav H, Hershko-Klement A, Solt I, Glikman D, Nir-Paz R. Pregnancyassociated listeriosis: many beliefs, few facts. Lancet Infect Dis 2015;15 1128-30.

10) Gupta V, Gautam V, Mehta N, Kumari I, Joshi RM. Listeriosis in second trimester of pregnancy: case report from India. Jpn J Infect Dis 2003; 56:60-1.

11) MacDonald PD, Whitwam RE, Boggs JD, MacCormack JN, Anderson KL, Reardon JW, et al. Outbreak of listeriosis among mexican immigrants as a result of consumption of illicitly produced mexican-style cheese. Clin Infect Dis 2005;40:677-82.

12) Chan LM, Lin HH, Hsiao SM. Successful treatment of maternal listeria monocytogenes bacteremia in the first trimester of pregnancy: a case report and literature review. Taiwan J Obstet Gynecol 2018;57:462-3.

13) Tai YL, Chi H, Chiu NC, Lin CY, Cheng JL, Hsu CH, et al. Clinical features of neonatal listeriosis in Taiwan: a hospital-based study. J Microbio Immunol Infect 2019 Aug 21 [Epub]. https://doi.org/10.1016/j.jmii.2019. 08.001.

14) Park JH, Ahn JH, Seo KJ, Choi SK, Park IY, Kim YH. Challenging management of chorioamnionitis with placental listeriosis: lessons from 2 cases. Obstet Gynecol Sci 2018;61:688-92. 